\title{
ПІДБІР КІЛЬКОСТЕЙ ДОПОМІЖНИХ РЕЧОВИН ПРИ СТВОРЕННІ КАПСУЛ З ГУСТИМ ЕКСТРАКТОМ ЧЕБРЕЦЮ ПОВЗУЧОГО З ВИКОРИСТАННЯМ РЕГРЕСІЙНОГО АНАЛІЗУ
}

\author{
() Н. О. Зарівна, О. В. Тригубчак
}

\author{
ДВНЗ «Тернопільський державний медичний університет імені І. Я. Горбачевського \\ МОЗ України»
}

zarivnanadia@ukr.net

\begin{abstract}
Мета роботи. Підбір кількостей допоміжних речовин при одержані порошкової маси на основі густого екстракту чебрецю повзучого.

Матеріали і методи. Густий екстракт чебрецю повзучого, який отримували згущенням у роторному випарювачі LABOROTA 4001 при температурі $80^{\circ} \mathrm{C}$ рідкого екстракту чебрецю повзучого. Дослідження впливу кількостей допоміжних речовин для одержання порошкової маси з густим екстрактом чебрецю повзучого проводили за допомогою регресійного аналізу (симетричний композиційний ротатабельний уніформ-план другого порядку).

Результати й обговорення. Вивчено вплив кількісних фракторів на показники якості порошкової маси 3 густим екстрактом чебрецю повзучого, за допомогою рівнянь регресії досліджено взаємозв'язок між ними. Встановлено, що збільшення кількості неусіліну UFL 2 позитивно впливає на швидкість течії через насадку, тоді як збільшення кількості натрію кроскармелози підвищує значення насипної густини суміші до і після усадки та значно зменшує кут природного укосу. Надаючи рівнянням регресії канонічного вигляду та провівши аналіз ліній рівного виходу отримано оптимальний склад порошкової маси з густим екстрактом чебрецю повзучого.

Висновки. На основі комплексу проведених досліджень запропоновано склад порошкової маси 3 густим екстрактом чебрецю повзучого: густого екстракту чебрецю повзучого (сухий залишок - 80 \%) в перерахунку на сухий - 0,075 г, неусіліну UFL 2 - 0,02 г, натрію кроскармелози - 0,022 г, МКЦ 101 - 0,078 г.
\end{abstract}

Ключові слова: густий екстракт; чебрець повзучий; капсули; допоміжні речовини; регресійний аналіз; кількісні фрактори.

Вступ. Хвороби органів дихання залишаються найбільш розповсюдженою патологією в структурі захворюваності населення України. Вони займають четверте місце після травматизму, серцево-судинних недуг і пухлинних процесів, досить часто закінчуються інвалідністю [1].

В останні роки все більшу популярність набувають препарати, виготовлені з лікарської рослинної сировини [2]. Вони при правильному дозуванні практично нетоксичні, нешкідливі, відносно доступні, ефективні і замінити їх синтетичними препаратами практично неможливо.

Згідно 3 даними літератури [1, 2], препарати на основі чебрецю повзучого призначають при бронхітах, запаленні легень, кашлюку як відхаркувальний засіб, фрармакологічна дія яких зумовлена складним комплексом біологічно активних речовин відповідної рослини (фенольні сполуки, компоненти ефрірної олії, полісахариди, фрлавоноїди тощо). Провівши аналіз ринку препаратів-муколітиків на основі трави чебрецю повзучого, встановлено, що частка українських виробників щодо іноземних становить $25 \%$ проти $75 \%$ [3].
Тому $є$ актуальною розробка нового вітчизняного лікарського засобу для лікування патологій дихальних шляхів на основі чебрецю. Як активні фрармацевтичні інгредієнти було використано густий екстракт чебрецю повзучого й ефрірну олію чебрецю звичайного.

У попередніх наших дослідженнях для оптимізації складу порошкової маси з досліджуваним екстрактом були вибрані речовини-лідери: неусілін UFL 2, натрію кроскармелоза, за допомогою яких ми отримали капсульну масу із задовільними фрармако-технологічними властивостями [4,5]. Відомо, що особливу увагу при розробці капсул слід приділити кількісному складу допоміжних речовин, які входять до лікарської форми і дозволяють отримувати капсули, які мають відповідати вимогам ДФУ [4]. Тому метою нашої роботи є підбір кількостей ДР при створенні капсул на основі густого екстракту чебрецю повзучого.

Матеріали і методи. Густий екстракт чебрецю повзучого отримували згущенням у роторному випарювачі LABOROTA 4001 при температурі $80^{\circ} \mathrm{C}$ рідкого екстракту чебрецю повзучого, технологія якого була запропонована нами раніше [6].

ISSN 2312-0967. Pharmaceutical review. 2017. № 2 
Фармацевтична технологія, біофармація, гомеопатія Pharmaceutical technology, biopharmacy, homeopathy

При створенні оптимального складу капсул на основі густого екстракту чебрецю повзучого було вивчено 2 кількісні фрактори. Перелік кількісних фракторів та їх рівнів наведено в таблиці 1.

Планування експерименту здійснювали за алгоритмом, який наведено в монографії «Математичне планування експерименту при проведенні наукових досліджень в фрармації» [7]. Матриця планування експерименту та результати дослідження показників якості порошкової маси з густим екстрактом чебрецю повзучого наведено в таблиці 2. Побудова матриці проводиться шляхом включення до плану експерименту дослідів, в умовах яких фрактори вивчаються на верхній « $+\alpha$ » і нижній « - $\alpha$ » зіркових точках.

Отримані суміші випробовували згідно з фрармакопейними вимогами [5] за показниками швидкості течії через насадку, насипної густини до та після усадки, а також кута природного укосу.

Результати й обговорення. При побудові математичних моделей виявляли тільки значущі фрактори. Адекватність рівнянь регресії перевіряли за допомогою F-критерію $\left(F_{0,16 \cdot 1}=58,204\right)$. Отримані моделі виявились адекватними, оскільки $\mathrm{F}_{\text {експ }}<\mathrm{F}_{\text {табл. }}$.

Залежність швидкості течії через насадку від кількостей обраних допоміжних речовин описується наступним рівнянням регресії $\left(F_{\text {експ }}=12,81\right)$ :

$$
\mathrm{y}_{1}=13,10-2,29 \mathrm{x}_{1}+4,77 \mathrm{x}_{2}+7,06 \mathrm{x}_{1}^{2}+4,25 \mathrm{x}_{2}^{2}
$$

При аналізі рівняння доцільно відзначити що нульовий коефріцієнт рівний 13,10. Це означає, що при введенні до складу порошкової маси з екстрактом чебрецю повзучого досліджуваних фракторів на основному рівні швидкість течії через насадку 13,10 c/100 г. На цей показник найбільше впливає кількість неусіліну UFL 2. Знак "+" перед квадратичним $\mathrm{x}_{1}^{2}$ коесріцієнтом регресії вказує на те, що при зміні значення рівнів фракторів у інтервалі від « - $\alpha$ » до « $+\alpha$ час висипання порошкової суміші збільшується. Додавання більшої кількості натрію кроскармелози також супроводжується підвищенням плинності порошкової маси з екстрактом чебрецю повзучого.

Вплив вивчених фракторів на насипну густину до усадки відображає наступне рівняння регресії $\left(\mathrm{F}_{\text {експ. }}=3,11\right)$ :

$$
y_{2}=0,73+0,08 x_{2}+0,06 x_{1} x_{2}
$$

3 цієї математичної моделі видно, що при додаванні до складу порошкової маси 1 г неусіліну UFL 2 та 2,5 г натрію кроскармелози насипна густина до усадки буде становити 0,73 г/мл. Суттєво зростає цей показник при додаванні більшої кількості натрію кроскармелози. Значний вплив на насипну густину до усадки проявляє взаємодія фракторів $\mathrm{x}_{1}$ i $x_{2}$.

Таблиця 1. Фактори та їх рівні, які вивчалися при розробці оптимального складу порошкової маси на основі

\begin{tabular}{|c|c|c|c|c|c|}
\hline \multirow[b]{2}{*}{ Фактор } & \multicolumn{5}{|c|}{ Рівень фрактора } \\
\hline & $\begin{array}{c}\text { нижня зіркова } \\
\text { точка } \\
\ll-\alpha »\end{array}$ & $\begin{array}{l}\text { нижній } \\
\text { «-1» }\end{array}$ & $\begin{array}{l}\text { основний } \\
\text { «0 }\end{array}$ & $\begin{array}{l}\text { верхній } \\
«+1 »\end{array}$ & $\begin{array}{c}\text { верхня зіркова } \\
\text { точка } \\
«+\alpha »\end{array}$ \\
\hline $\begin{array}{l}\text { X } 1 \text { - кількість неусіліну UFL 2, г на } \\
50 \text { капсул }\end{array}$ & 0,293 & 0,5 & 1,0 & 1,5 & 1,707 \\
\hline $\begin{array}{l}\text { X } 2 \text { - кількість натрію кроскармелози, } \\
\text { г на } 50 \text { капсул }\end{array}$ & 1,086 & 1,5 & 2,5 & 3,5 & 3,914 \\
\hline
\end{tabular}
густого екстракту чебрецю повзучого

Таблиця 2. Матриця планування експерименту і результати дослідження порошкової маси з густим екстрактом чебрецю повзучого

\begin{tabular}{|c|c|c|c|c|c|c|}
\hline № cepiï & $\mathrm{x}_{1}$ & $\mathrm{x}_{2}$ & $\mathrm{y}_{1}$ & $\mathrm{y}_{2}$ & $\mathrm{y}_{3}$ & $\mathrm{y}_{4}$ \\
\hline 1 & + & + & 23,49 & 0,85 & 0,89 & 20 \\
\hline 2 & - & + & 33,64 & 0,78 & 0,83 & 25 \\
\hline 3 & + & - & 17,74 & 0,59 & 0,71 & 28 \\
\hline 4 & - & - & 14,15 & 0,75 & 0,83 & 25 \\
\hline 5 & $+\alpha$ & 0 & 25,23 & 0,61 & 0,70 & 28 \\
\hline 6 & $-\alpha$ & 0 & 33,54 & 0,61 & 0,70 & 28 \\
\hline 7 & 0 & $+\alpha$ & 28,31 & 0,78 & 0,81 & 25 \\
\hline 8 & 0 & $-\alpha$ & 19,18 & 0,56 & 0,63 & 29 \\
\hline 9 & 0 & 0 & 13,85 & 0,70 & 0,72 & 28 \\
\hline 10 & 0 & 0 & 12,31 & 0,75 & 0,78 & 25 \\
\hline
\end{tabular}

Примітка: $y_{1}$ - швидкість течії через насадку, с/100 г; у ${ }_{2}$ - насипна густина до усадки, г/мл; $y_{3}-$ насипна густина після усадки, г/мл; $\mathrm{y}_{4}-$ кут природного укосу, .

ISSN 2312-0967. Фармацевтичний часопис. 2017. № 2 
Характер впливу кількостей досліджуваних фракторів на насипну густину після усадки для порошкової маси з екстрактом чебрецю повзучого виражається рівнянням регресії $\left(\mathrm{F}_{\text {експ. }}=1,98\right)$ :

$$
\mathrm{y}_{3}=0,75+0,05 \mathrm{x}_{2}
$$

При вивченні досліджуваних оракторів на основному рівні порошкова маса з екстрактом чебрецю повзучого після усадки має густину 0,75 г/мл. Значення насипної густини після усадки залежить від кількості натрію кроскармелози, а саме - збільшення фрактора $\mathrm{x}_{2}$ в інтервалі від « - 1» до « + 1» збільшує цей показник на 0,05 г/мл.

Взаємозв'язок між вивченими фракторами та кутом природного укосу описується рівнянням регресії $\left(\mathrm{F}_{\text {експ. }}=0,75\right)$ :

$$
\mathrm{y}_{4}=26,52-1,71 \mathrm{x}_{2}
$$

3 рівняння регресії випливає, що при вивченні $\mathrm{x}_{1}$ та $x_{2}$ на основному рівні кут природнього укосу становить 26,52, що згідно з вимогами ДФУ [7] вказує на дуже хорошу текучість, тобто маса не зависає, допоміжне устаткування непотрібне. Досліджуваний показник знижується при додаванні більшої кількості натрію кроскармелози.
Фармацевтична технологія, біофармація, гомеопатія Pharmaceutical technology, biopharmacy, homeopathy

При виборі оптимальних кількостей допоміжних речовин для порошкової маси з екстрактом чебрецю повзучого отримані рівняння регресії приводили до канонічного вигляду і на основі перетворених моделей будували лінії рівного виходу у системі координат $\mathrm{x}_{1} \mathrm{x}_{2}$ (рис. 1).

У результаті аналізу ліній рівного виходу (рис. 1) оптимальний склад зазначається при $\mathrm{x}_{1}=$ «0», $\mathrm{x}_{2}=$

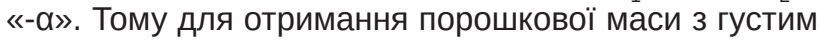
екстрактом чебрецю повзучого доцільно використовувати 1 г неусіліну UFL 2 та 1,086 г натрію кроскармелози з розрахунку на 50 капсул. МКЦ 101 додавали в різних кількостях для доведення маси досліджуваної суміші до середньої маси 0,195 г.

Висновки. 1. Для оптимізації складу порошкової маси $з$ густим екстрактом чебрецю повзучого при розробці твердих капсул, застосовуючи регресійний аналіз, підібрано кількості ДР, а також досліджено їхній вплив на показники якості капсульної маси. В результаті комплексу проведених досліджень визначено оптимальний склад порошкової маси з густим екстрактом чебрецю повзучого: густого екстракту чебрецю повзучого (сухий залишок - 80 \%) в перерахунку на сухий - 0,075 г, неусіліну UFL 2 - 0,02 г, натрію кроскармелози - 0,022 г, МКЦ $101-0,078$ г.

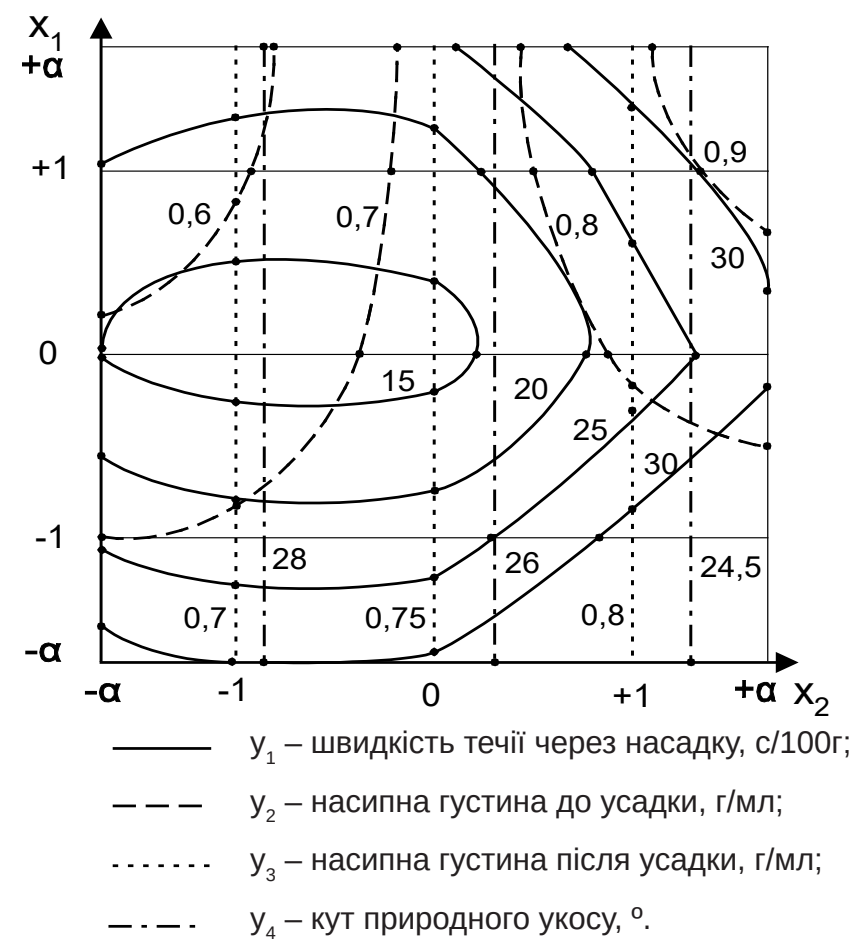

Рис. 1. Лінії рівного виходу в системі координат $\mathrm{x}_{1} \mathrm{x}_{2}$ за результатами перетворених рівнянь регресії.

ISSN 2312-0967. Pharmaceutical review. 2017. № 2 
Фармацевтична технологія, біофармація, гомеопатія

Pharmaceutical technology, biopharmacy, homeopathy

\title{
ПОДБОР КОЛИЧЕСТВ ВСПОМОГАТЕЛЬНЫХ ВЕЩЕСТВ ПРИ СОЗДАНИИ КАПСУЛ С ГУСТЫМ ЭКСТРАКТОМ ТИМЬЯНА ПОЛЗУЧЕГО С ИСПОЛЬЗОВАНИЕМ РЕГРЕССИОННОГО АНАЛИЗА
}

\author{
Н. О. Заривна, О. В. Трыгубчак \\ ГВУЗ «Тернопольский государственный медицинский университет имени И. Я. Горбачевского \\ МЗ Украины» \\ zarivnanadia@ukr.net
}

Цель работы. Подбор количества вспомогательных веществ при получении порошковой массы на основе густого экстракта тимьяна ползучего.

Материалы и методы. Густой экстракт тимьяна ползучего получали сгущением в роторном испарителе LABOROTA 4001 при температуре $80{ }^{\circ} \mathrm{C}$ жидкого экстракта тимьяна ползучего. Исследование количеств вспомогательных веществ для получения порошковой массы с густым экстрактом тимьяна ползучего проводили с помощью регрессионного анализа (симметричный композиционный ротатабельний униформ-план второго порядка).

Результаты и обсуждение. Изучено влияние количественных фракторов на показатели качества порошковой массы, с помощью уравнений регрессии изучено взаимосвязь между влиянием фракторов. Установлено, что увеличение количества неусилина UFL 2 положительно влияет на скорость течения через насадку, тогда как увеличение количества натрия кроскармеллозы повышает значение насыпной плотности смеси до и после усадки и значительно уменьшает угол естественного откоса. Приведя уравнения регрессии к каноническому виду и проанализировав линии равного выхода, определен оптимальный состав порошковой массы с густым экстрактом тимьяна ползучего.

Вывод. На основе комплекса проведенных исследований предложен состав порошковой массы с густым экстрактом тимьяна ползучего: густого экстракта тимьяна ползучего (сухой остаток - 80 \%) в пересчете на сухой 0,075 г, неусилина UFL 2 - 0,02 г, натрия кроскармеллозы - 0,022 г, МКЦ 101 - 0,078 г.

Ключевые слова: густой екстракт; тимьян ползучий; капсулы; вспомогательные вещества; регрессионный анализ; количественные фракторы.

\section{CHOOSING QUANTITIES OF EXCIPIENTS FOR THE DEVELOPMENT OF CAPSULES WITH THICK EXTRACT OF CREEPING THYME BY USING REGRESSION ANALYSIS}

\section{N. O. Zarivna, O. V. Tryhubchak}

\section{Horbachevsky Ternopil State Medical University zarivnanadia@ukr.net}

The aim of the work. Choosing of quantities of excipients for the preparation of the powder mass on the basis of thick extract of creeping thyme.

Materials and Methods. Thick extract of creeping thyme, which received thickening in rotary evaporator LABOROTA 4001 at $80^{\circ} \mathrm{C}$ of liquid extract of creeping thyme. Research quantities of excipients in developing of powder mass with thick creeping of thyme extracts was performed by using regression analysis (the symmetrical composition rototabel uniform plan of the second order).

Results and Discussion. We studied the effect of quantitative factors and established the relationship between them by using regression equations. It was found that increasing the number of neuselin UFL 2 has positive effect on the rate of flow through the nozzle, while increasing the number of sodium croscarmellose increases the value of bulk density of the mixture before and after shrinkage and significantly reduces the angle of repose. Providing canonical form for equation regression analysis and conducting line of level output we obtained the optimal composition of powder mass with thick extract of creeping thymel.

Conclusion. We proposed the content of powder mixture with thick extract of creeping thyme: thick extract of creeping thyme (the dry residue $-80 \%$ ) in terms of dry $-0,075 \mathrm{~g}$, neuselin UFL $2-0.02 \mathrm{~g}$, sodium croscarmellose $-0.022 \mathrm{~g}$, MCC $101-0,078 \mathrm{~g}$.

Key words: thick extract; creeping thyme; capsules; excipients; regression analysis; quantitative factors.

ISSN 2312-0967. Фармацевтичний часопис. 2017. № 2 
Фармацевтична технологія, біофармація, гомеопатія Pharmaceutical technology, biopharmacy, homeopathy

\section{Список літератури}

1. Зайцева О. В. Рациональный выбор муколитической терапии в комплексном лечении осложненных пневмоний и хронических болезней органов дыхания / О. В. Зайцева, А. Б. Левин // Consilium medicum. - 2004. - T. 6, № 3. - С. 175-179.

2. Товстуха $€$. С. Фітопрепарати - лікарські засоби майбутнього / Є. С. Товстуха // Фітотерапія в Україні. 1998. - № 2-3. - С. 20-21.

3. Зарівна Н. О. Аналіз ринку лікарських засобів на основі чебрецю звичайного / Н. О. Зарівна, Л. В. Вронська, М. М. Михалків // Фармацевтичний часопис. - 2010. - № 4. - С. 59-63.

4. Зарівна Н. О. Вибір допоміжних речовин для отримання твердих капсул з густим екстрактом чебрецю

\section{References}

1. Zaitseva OV, Levin AB. [Rational choice of mucolytic therapy in the complex treatment of complicated pneumonia and chronic respiratory diseases]. Cons. medic. 2004;3: 175-79. Russian.

2. Tovstukha ES. Phytomedication - drugs of the future Phitoterapiia v Ukraini. 1998; 2-3: 20-1. Ukrainian.

3. Zarivna NO, Vronska LV, Mykhalkiv MM. [Market analysis of drugs based on thyme]. Farmatsevt chasop. 2010;4 59-63. Ukrainian.

4. Zarivna NA, Hroshovyi TA, Vronska LV [Choice of excipients for solid caps with thick creeping thyme extract]. Farmatsevt chasop. 2012;4: 43-6. Ukrainian.

5. State Pharmacopoeia of Ukraine: in 3 vol. / State En- повзучого / Н. О. Зарівна, Т. А. Грошовий, Л. В. Вронська // Фармацевтичний часопис. - 2012. - № 4. - С. 43-46.

5. Державна фрармакопея України: в 3 т. // Державне підприємство «Український науковий експертний фрармакопейний центр якості лікарських засобів». - 2-е вид. - Харків : Державне підприємство «Український науковий експертний фрармакопейний центр якості лікарських засобів», 2015. - Т. 1. - 1128 с.

6. Пат. Україна №73543, Спосіб отримання рідкого екстракту чебрецю повзучого / Зарівна Н. О., Вронська Л. В., Грошовий Т.А.; опубл. 25.09.2012, Бюл. № 18.

7. Математичне планування експерименту при проведенні наукових досліджень у фрармації / [Т. А. Грошовий, В. П. Марценюк, Л. І. Кучеренко та ін.]. - Тернопіль : Укрмедкнига, 2008. - 367 с.

terprise "Ukrainian Research Center expert pharmacopoeia quality medicines." - 2nd ed. - Kharkiv State Enterprise "Ukrainian Research Center expert pharmacopoeia drug quality," 2015; 1: 1128. Ukrainian.

6. Zarivna NA, Vronska LV, Hroshovyi TA, inventors; Ternopil State Medical University,assignee. Method creeping thyme liquid extract UA 73543 (Patent) 2012 Sept. 25. Ukrainian.

7. Hroshovyi TA, Martsenyuk VP, Kucherenko LI, Vronska LV, Huryeyeva CM. Mathematical planning of experiment in pharmacy. [Математичне планування експерименту в фрармації]. Ternopil: Ternopil State Medical University; 2008. Ukrainian. 